\title{
The Future of Our Past
}

\section{An Address Delivered Before the North Carolina State Meeting of the Colonial Dames of the XVIIth Century}

March 21, 2003

by Thomas Kevin B. Cherry

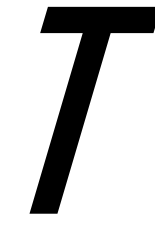

here are so many tales that can be told, but thinking about the future of our past, I think that tonight, I'Il tell you a story about "Shocco" Jones. ${ }^{1}$

Joseph Sewell Jones was born around 1806 in Warren County, along the banks of Shocco Creek. His father was a fairly well-to-do planter and his mother was the niece of one of North Carolina's leading statesmen, Nathaniel Macon - the decidedly anti-federal ist politician. It was said about Jones, a few years after his death: "The time has been when the sayings and doings of this singular personage were chronicled with as much avidity as is displayed by the Court Journal in the narration of the British Queen." He was an antebellum media darling, a lawyer, politician (of sorts), prankster, and puller of hoaxes as big as his tales were tall.

Jones got his nickname, "Shocco," for his hometown creek, while attending the university in Chapel Hill. There were other Joneses among the student body, and his fellows decided to set him apart - as did the faculty, when, after two and a half years, they examined his grades and tallied up his absences and found that the Warren County boy was not quite a scholar - and for that matter, at ninety-eight absences, hardly a student at all. They sent him home. A couple of years passed, and Shocco did what just about anybody who has flunked out of Carolina would, I suppose, do. He went off to attend Harvard Law School, where, after dropping out three times, he was finally given a degree in 1839.

Shocco didn't become famous as a lawyer, al though he was a good talker. One of the best. He was what we today would call a "people person." He knew everybody. As one man remembered at Shocco's death, "He was full of anecdote. He knew Van Buren, Jackson, both Adamses, Calhoun, Clay, Randolph, and every man who had figured on the world's stage for the thirty years past, and had anecdotes to tell of each. He knew the private history of everybody who had any 'private history,' and danced with the belles of two generations, had dined with all of the foreign ministers of seven administrations, and was au fait of all the political and domestic scandal of Washington for as many reigns." (Au fait is French for "in on the doings.")

Stories of Shocco's exploits abound. I'm not going to tell you about the time he claimed to have killed a man during a duel near Portsmouth, Virginia, caused an Edenton schoolmaster to switch clothes with him to help him "escape" from the dueling grounds, and then - of course - manage to make all of the national newspapers. (Shocco produced the bloody battleground, a witness who had heard 
the shots, and a red-stained handkerchief in the midst of his tale, but he never could produce the poor ill-aiming corpse. It was up to the perplexed schoolmaster to return to the dueling grounds some days later, and there he found the unfortunate victim - a pig - "nothing more than a Pasquotank Roaster.")

I'm not going to tell you how he invented a beautiful sister-in-law for colonial governor William Tryon, a young lady by the name of Miss Esther Wake, and had folks believing that it was for her the state's capital county was named - even the people of New Bern, who, for the life of them couldn't remember a neighbor by that name - which was odd because she was so good looking, after all. Still, there she was in print, so she had to have existed. As late as the twentieth century, a noted historian was to fall for this Shocco hoax.

I definitely won't go into how Warren County's Shocco Jones wandered in to economically hard hit, Columbus, Mississippi (a few steps ahead of men interested in speaking with him about that faked duel) carrying two large parcels, one labeled "Cape Fear Money" and the other "public documents." Shocco announced to the Mississippians that he was an agent for the Bank of the Cape Fear looking to make investments in that part of the world. The local folks who hadn't seen hard money in a long time could hardly take their eyes off that package marked "Cape Fear Money." But then Shocco told the salivating bank tellers that he was also an agent for the U.S. Treasury Department come to get the local banks to repay the deposited federal funds that had been lost in a recent economic failure. I can imagine how fast those greedy Mississippi eyes traveled over to that other packet labeled "public documents." Shocco Jones had those poor Mississippians living a mixture of shaky nerves and green greed. Needless to say, the potential investor/forecloser (Shocco) was wined and dined by everyone who was anyone - including the governor of the state. Everybody wanted to be on Shocco's good side. And this lasted for about six months until the North Carolina talker gave a federal marshal a wrong answer to an innocuous question, and his charade was discovered - but by the time Mississippians could come after him, Shocco Jones was in Alabama, and the parcels he left behind they discovered to be full of nothing but newsprint and blank sheets of paper. Newsprint and blank sheets of paper!

Wouldn't that make a good movie? I'll not tell that story.

No, I'm going to tell you what happened when Shocco Jones took issue with Thomas Jefferson who had once stated that the Mecklenburg Declaration of Independence, North Carolina's legendary document - which claimed to be the first statement of independence by any of the colonies - was spurious. An insult! Jefferson had also said that "we had no greater Tory in Congress" than William Hooper, one of North Carolina's signers of the Declaration of Independence. A double insult! Someone must stand up for North Carolina's honor! Shocco rose to the occasion. Knowing his track record, the Warren County Jones probably would have challenged Thomas Jefferson to a duel right then and there upon hearing the sentences uttered, but the sage of Monticello was al ready dead. (Of course, that would have fit right in to Jones's style of dueling. He al ways came out better in the test of arms when he wasn't opposed.)

At any rate, Shocco set out to do the next best thing - prove Thomas Jefferson to be a base liar. The Warren County boy, Carolina drop-out, and Harvard law school student decided to write a book, and, in 1832, during one of his many hiatuses from law school, spent months collecting materials and interviewing el derly Tar Heels "from Cape Hatteras to the Blue Ridge." He was diligent. Shocco was allowed to consult the official papers of the state (now you would call what he looked at, the State Archives). He also sought out and investigated private papers of the state's leaders and leading families. And believe it or not, he wrote his book. His Defence of the Revolutionary History of the State of North Carolina from the Aspersions of Mr. Jefferson, appeared in September 1834. It was well received, especially in North Carolina. But that's not the end of the story, of course.

People began to wonder what happened to all of that material, the letters and the papers, that Shocco had managed to collect while writing his book. The way 
Jones spoke of them, the raw materials he used must have been invaluable. Most people who cared about these things - especially Governors William A. Graham and David Lowry Swain - figured that Shocco Jones, even though he was in quite a hurry when his neighbors last saw him, must have taken those valuable letters and papers to Mississippi with him. That was not the case. When he fled his native state on the way to the Old Southwest, Shocco Jones left a trunk full of papers with a relative. And when that relative left the state, the trunk was given to yet another man. This man figured that the trunk must hold something valuable, and, without looking inside, he put it in the Raleigh branch of the Bank of Cape Fear. The trunk and its contents sat there for fifteen years, while leaders of the state looked for it. The governor tried to get Shocco Jones, who had returned to Mississippi, to give the papers to the people of North Carolina. Jones just kept saying, "They're already in the state," but he wouldn't say where.

When the talented talker and big-time hoaxster died in 1855 (after living his final years as a hermit in a cabin in the woods), the search for the famous papers heated up, and the University of North Carolina's president, former governor David Lowry Swain, ran a note in a student publication, asking if anyone had any clues about where Shocco Jones may have hidden his trunk full of papers. The Jones family friend, that third party, read this notice and thought, "Could that be the trunk I put in the bank?" and he invited the powers-that-be to come take a look.

I know what you are all now expecting me to say. You think I am going to say, "That trunk was full of newsprint and blanks sheets of paper." But it wasn't. I guess you could think of it, in a way, as Shocco Jones's reverse hoax - or double hoax. Sitting here 148 years later, we expect to be tricked by Ol' Shocco, but we aren't so we were tricked, after all.

There, just as if they had been tossed in fifteen minutes before and not twenty years before, were manuscript records from North Carolina's Revolutionary War leaders - Joseph Graham, James Iredell, Sr., Richard Henderson, and Samuel Johnston, among others - true treasure, if ever North Carolina could claim one. If they ever finally do find Blackbeard's trunk, it couldn't hold anything more valuable. These papers tell OUR story. Preserved. Shocco Jones, the "Mammouth Humbug," as he came to be known during his day, had managed to collect and save primary source material that is still being consulted today by historians and other researchers. It is the raw material the true stuff of history - and we should all tip our hats to him.

That is all well and good, you say, but the title of your talk is "The Future of the Past." What does Shocco Jones have to do with that? A great deal as it turns out. Shocco Jones could put his papers in a box, lock them up, and sit them in a vault, run off to Mississippi, and die. His papers could molder and grow dusty, but somebody, someday, was going to open that trunk. You just don't leave trunks sitting in bank vaults forever and not have them opened at some point by somebody. That is the way a great many of our old records - the evidence upon which we base our stories and our memories - come to us. They sit in an attic or a basement or a closet or a shoebox under a bed or a filing cabinet in an office, and they age. The letter from Aunt Janie at ten years old is "ok," maybe interesting, but that same letter from Aunt Janie after 90 more years will grab your attention. Then, these attentiongrabbing pieces of paper (and now photographs and even audio- and videotapes) find their way to our libraries, museums, and archives.

Today, the professionals responsible for preserving and maintaining the records of the human enterprise are faced with a daunting task. They are facing a sea of information, no longer tied in red ribbons and stored in shoeboxes, but encased in the hard plastic shells of computers. ${ }^{2}$ I can't go home tonight, grab my computer, and carry it down to the closest branch of the State Employees Credit Union and say, "Could you put this in the vault. Someone is going to come get it out in fifty years, and they'll want to see what I have stored in it." First of all, a computer can't hold information that long. Its storage capability is highly unstable. The piece of the computer upon which the information is stored will break down over a relatively short period of time, and the information in that computer will be lost. Second, 
even if we could make the computer able to store the information for as long as paper (and a good piece of paper can last hundreds of years), the software used to read that computer information is al ways changing. Any of us who have computers know about "upgrades." If we have that imaginary indestructible computer fifty years from now, there probably will be very few - if anyone - who have kept the tools that can get the information out of it. And more and more of our business and our government and our personal life (anybody heard of e-mail?) is conducted through electronic - computer - information. ${ }^{3}$ If we want the folks in the future to know what happened during "our days," to be able to tell our stories with as much relish as I can talk about ol' Shocco, then we must come to terms with how to "archive" computer-based, electronic records. ${ }^{4}$

I am happy to report that it is possible to preserve electronic information. Some of the top minds in the country have stepped up to this challenge, but to do so takes a great deal of planning and constant management of the computers and their information. We can save the records of our days, but we can't do it by imitating Shocco Jones. We can't stuff them in a box and run off to Mississippi. ${ }^{5}$

\section{If we want the folks in the future to know what happened during "our days," to be able to tell our stories with as much relish as I can talk about ol' Shocco, then we must come to terms with how to "archive" computer-based, electronic records.}

I grew up on a tomato farm, and I like to compare saving el ectronic records to the work of a farmer, which never ceases. You make it through one season, and it is time to begin working for the next, that leads to the next, which brings you back where you started. We may say we do, but we never truly lay our crops by, and in the archives of today, we never get to the point where we can lay those electronic records by like Shocco Jones did. The equivalent of spring comes, and you have got to replant onto another computer storage disk, harvest information from yet another, or prepare a new field of computers for a fresh planting. It's continual. It's labor intensive. And it must be done.

I am president of the Friends of the State Archives of North Carolina. I am a member of this organization because I want to do my small part to help preserve the records of the state of North Carolina, and the best way I can think to do this, is to be a member of an organization that supports the workers of our state's chief archival agency. No other group of people works harder to address issues such as the potential loss of electronic records than do the folks in our State Archives. They believe strongly in preserving the memory of the people of North Carolina. They take it seriously. It is their mission. And they know what a huge task looms before them. Still, they plug along, and they are optimistic, even though there are now seventythree fewer employees in our state's Division of Archives and History than there were approximately ten years ago (and it was not that big a unit to begin with). ${ }^{6}$

We await a new round of budget cuts as we meet here tonight. North Carolina is not al one in this type of reductions. In Florida, the governor has proposed cutting that state's archives to the bone - actually, past the bone - and shuttling it off to a department like Environmental Protection, essentially doing away with a full archival program. ${ }^{7}$ The former mayor of New York City has attempted to pull his public papers and place them in a private repository - a scary proposition for researchers' full access - claiming that the municipal archives don't have the resources to handle them. ${ }^{8}$ Of course, it was his administration, which had cut those resources to that department to begin with. I could continue along these lines, but I will cut to the chase: public support of archival and related programs across the country is being cut at the very time when archives and archivists are facing their greatest challenge ever. EVER. At no other time has mankind faced the proposition of losing so many of its records, the materials upon which we base our corporate memory. When those records are gone, they are gone forever. They cannot be recovered.

I am telling you this because I know you care about these things. I know the 
good work that your organization and others like it do and have done through the years. The Colonial Dames know the value of preserving the past to help us all understand our present and prepare for our future. I am telling

At no other time has mankind faced the proposition of losing so many of its records, the materials upon which we base our corporate memory. When those records are gone, they are gone forever. you this because I think you can help. Support the archives, join the Friends of the Archives as individuals and as a group. ${ }^{9}$ Let people know of your interest in maintaining the state's official records - and the challenge their official caretakers, the state's archivists, face. Carry the message. Spread the word. Help where you can. And if you are kin to a legislator, bend an ear. I know we will be successful. We have to be, if we are to be able to tell the stories of today to the Tar Heels of the future.

At this time of challenge, if we are to preserve our records successfully, we must give our "preserving" institutions greater support. If we do not, when someone "opens" that huge computer of the future, he will find the electronic equivalent of Shocco Jones's old newsprint and blank sheets of paper. We can't let that happen to our history, our stories.

Note: This is a slightly shortened and edited version of the original address.

\section{References}

1 The tale of Shocco Jones is based upon the accounts in H.G. Jones, For History's Sake: The Preservation and Publication of North Carolina History 1663-1903 (Chapel Hill: University of North Carolina Press, 1966): 157-65; Edwin Miles, "Joseph Seawell Jones of Shocco - Historian and Humbug," North Carolina Historical Review 30 (Oct. 1957): 483506.

2 For a much-cited discussion, see Paul Conway, Preservation in the Digital World (1996), located at http://www.clir.org/pubs/abstract/pub62.html

3 Helen Tibbo of the School of Information and Library Science at UNC-Chape Hill and Duke University Archivist Tim Pyatt are currently involved in an important, federally funded study of the way university employees organize and maintain their e-mail records. As recent events such as the Columbia shuttle disaster have indicated, the often dashed off, informal email messages are beginning to be treated as records, just as if they had been placed in an envelope with a stamp and then stored in manila folders inside a filing cabinet.

4 A good resource for a fuller discussion of electronic preservation may be found on the Digital Library Federation's preservation Web site located at http://www.diglib.org/ preserve.htm

5 For an overview of electronic records, see the National Archives and Records Administration's “Electronic Records Archives," located at http://www.archives.gov/ electronic_records archives/index.html

6 According to North Carolina Division of Archives and History's Director of Historical Resources David Olson, at a Friends of the Archives Board meeting, Mar. 17, 2003.

7 Mark Lane "'State of Readers' Could Close State Library, Scatter Archives," Daytona Beach News-Journal, Jan. 28, 2003, viewed on Mar. 10, 2003 at http://www.njcenter.com/NewsJournal Online/News/Local/areaAREA3012903.htm See also Bruce Craig, "History Hit Badly by Proposed Budget Cuts in Florida and New Jersey," Perspectives Online [the newsmagazine of the American Historical Association], Mar. 2003, viewed on Mar. 10, 2003, at http://www.theaha.org/Perspectives/issues/2003/0303/ 0303new2.cfm

8 Newsday.com, http://www.newsday.com/news/local/newyork/ny-pap1004.story. See also, Wayne Barrett, "Hijacking History," Village Voice, Jan. 23-29, 2002, both viewed on Mar. 10, 2003, at http://www.villagevoice.com/issues/0204/barrett.php

9 The Web site for the Friends of the Archives may be found at http:// www.ah.dcr.state.nc.us?Affiliates/Foa/FOA.htm 